\title{
Baseline study of growers' constraints in the production of apple (Malus domestica) in Plateau State Nigeria
}

\author{
U. G. Osadebamwen ${ }^{1 *}$ (D, A. E. Adekoya ${ }^{1}$ and E. A. Akintunde 2
}

\begin{abstract}
Background: Including temperate fruits like apples in her production and export line is one of the many ways Nigeria, particularly, Plateau State, can diversify her economy and consequently address the issues of poverty, malnutrition, and hunger. However, there are constraints confronting the industry. This research was carried out as a baseline study of growers' constraints in the production of apple in Plateau State, Nigeria.

Method and result: Multi-stage sampling procedure was used to select the respondents for this study. Plateau State has 17 local government areas (LGAs) out of which four LGAs, namely, Jos South, Jos North, Barki Ladi and Riyom were purposively selected because of the prevalence of apple growers in these areas. Furthermore, the snowball sampling technique was used to achieve an enumeration of 30 apple growers, which were used for the study (total sampling). A well-structured interview schedule was used to collect both quantitative and qualitative data from respondents and the former was subjected to statistical analysis using descriptive statistics (means and percentages) while the latter was done using focused group discussions (FGDs) and analysed using qualitative tools such as Problem Tree Analysis (PTA) and Paired Needs Priority Ranking (PNPR). Research findings revealed that lack of extension services $(\bar{x}=1.93)$, inadequate finance/credit facilities ( $\bar{x}=1.90)$ and high cost of farm inputs $(\bar{x}=1.83)$ were the most severe constraints to apple production in the study area. Using the PTA of low apple production in the study area, participants viewed lack of extension services, high cost of seedlings, inadequate/inaccessible credit facilities amongst others, as causes (roots) of the problem while high dependency ratio, low wages, loss of foreign exchange, etc., as the effects (fruits) of low apple production output. Furthermore, the PNPR revealed that subsidised farm inputs (especially cost of apple seedlings), extension services and credit facilities were the priority needs of the apple producers while receiving of market reports was their least prioritised need.
\end{abstract}

Conclusion: The study concludes that lack of extension services, inadequate finance/credit facilities and high cost of farm inputs were the most severe constraints to apple production in Plateau State, Nigeria. The study culminates with a list of suitable recommendations.

Keywords: Baseline study of Jos apples, Apple growers' constraints, Apple production in Plateau State, Problem Tree Analysis, Paired Needs Priority Ranking

*Correspondence: osadebamwenuyiosa28@gmail.com

${ }^{1}$ Department of Agricultural Extension and Rural Development, University of Ibadan, Ibadan, Nigeria

Full list of author information is available at the end of the article

\section{Introduction Background}

Growing fruits offers tremendous opportunities for enhancing the incomes of small-scale farming families in Nigeria and elsewhere in Africa especially if the exotic temperate species that are recognised and valued original author(s) and the source, provide a link to the Creative Commons licence, and indicate if changes were made. The images or other third party material in this article are included in the article's Creative Commons licence, unless indicated otherwise in a credit line to the material. If material is not included in the article's Creative Commons licence and your intended use is not permitted by statutory regulation or exceeds the permitted use, you will need to obtain permission directly from the copyright holder. To view a copy of this licence, visit http://creativecommons.org/licenses/by/4.0/. The Creative Commons Public Domain Dedication waiver (http://creativeco mmons.org/publicdomain/zero/1.0/) applies to the data made available in this article, unless otherwise stated in a credit line to the data. 
by domestic consumers are considered while not also neglecting the indigenous tropical ones. However, local cultivation of the valued temperate fruits such as apples, strawberries, grapes, mulberries, peaches, plums, apricots, cherries, etc., may turn out to be more profitable compared to indigenous tropical fruits particularly because of their higher market prices [1].

Various authors [2-7] have identified the prospects of tropical zones for the commercial production of temperate fruits like apples. The trend has been to locate orchards in the highlands of the tropical areas, because of their lower temperatures. Whereas sub-Saharan Africa is located in the tropics, there are pockets of areas with micro-climates that are typical of temperate and subtropical zones. These areas present ample opportunity to produce temperate fruits like apples, ceteris paribus, e.g., the Western Cape in South Africa, the Iringa region in Tanzania, the Nyere region in Kenya, the Batu region (East Java) in Indonesia, etc. These areas reflect the altitudelatitude dynamics. Whereas Western Cape is cool based on latitude, the Iringa region has a cool climate based on altitude and apple production have thrived in these areas alike. But of recent, the lowlands of tropical areas are experiencing an increase in the number of planted apple orchards. The cultural practices employed, and the yield of the plants vary depending on location and other sitespecific factors.

Hauser [8] posited that apples thrive well in hot climates and the tropics, where there are very few or zero chilling hours and hot days. Various researchers [9-12], have proven that using tropic apple culture methods can make the tree believe that its chilling-hour requirements have been satisfied and consequently it will blossom and fruit. Nonetheless, there is the need to be knowledgeable about which cultivars to plant as some varieties are more adapted to the tropics than others. Additionally, apple trees will behave much differently in a tropic climate as compared to what is obtainable in a temperate climate, but the result is still apples that are crisp, juicy and tasty [12].

Over the years, there has been an increasing demand for temperate fruits like apples, strawberries, grapes, etc., in the tropics and this may have triggered an interest in the production of these crops as shown by the upward trend of growing temperate crops in tropical regions of the world, e.g., Kenya, Zimbabwe, etc. [13]. Additionally, the high-altitude areas of the tropics (with their cooler climate) have been the preferred location for the cultivation of these crops. Nigeria is also in the list of temperate fruit producing nations and although the enterprise has been in existence for a long time spanning many decades, yet the industry is at ebb.
Observations were carried out in Nigeria on two apple cultivars, Anna, and N.28 (as pollinator), in three plantations located at Tenti (near Jos), Vom and Kano, respectively. The positive results obtained from the trials reconfirmed the possibility of apple cultivation in strictly tropical areas and particularly in Nigeria. The trial by [10] was one of the few recorded accounts of apple production trials carried out in Plateau State ${ }^{1}$. Surveys (interviews of stakeholders of the apple production industry) revealed that apple production trials were also conducted by other institutions like the Plateau Agricultural Development Agency (PADP), the Agricultural Services and Training Centre (ASTC), United Trading Company (UTC) Farms, etc.; however, a trend of poor record keeping and an ineffective system of fact documentation have been responsible for the loss of a great deal of information on apple production in Nigeria and particularly in Plateau State.

Despite the long period of time (spanning over two decades) since the trial by [10] was carried out, there has been no other documented scientific research (since that time), on the current condition of the apple production enterprise in Nigeria (particularly in Plateau State). In fact, the notion that the apple enterprise once thrived in the State coupled with the possibility of continuing/ expanding the enterprise is often greeted with skepticism in the faces of most Nigerians. An evaluation of the thread about apple production on Nairaland [14] (one of Nigeria's top social media platform) buttresses the current high level of skepticism on the subject. A baseline study will provide useful information that will help to bridge this knowledge gap while also presenting relevant stakeholders with the requisite data needed to make informed decisions to address the constraints being faced by growers and culminating in optimised apple production in Plateau State. The State is the hub of temperate fruit cultivation in general, especially apple production and this could be attributed to the near temperate (or sub-tropical) climate that is prevalent in the highland areas of the State.

According to the Brookings Institution [15], Nigeria with a population of about 200 million people [16] has already replaced India with a population of 1.3 billion people [17] as the country with the largest number of extreme poor in the World. Trajectories suggest that as of May 2018, Nigeria had about 87 million people in extreme poverty, as compared with India's 73 million. This implies that 1 in 2.4 Nigerians are in extreme poverty as against 1 in 18 Indians. To improve the standard of living of her citizenry, successive governments in Nigeria (especially since her return to democracy) have made

1 "Plateau State" was used interchangeably with "State" in this work. 
efforts to diversify the economy from its almost total reliance on oil; and consequently, the agricultural sector has again received prominent attention in the diversification agenda. Studies [18-21] have reported the relationship between crop diversification and poverty alleviation through creation of jobs and the consequent contribution to rural incomes. Including temperate fruits like apples in her production and export line is one of the many ways Nigeria can diversify her economy and consequently address the issues of poverty, malnutrition, and hunger.

Furthermore, some 83.14 million metric tons of apples were grown worldwide in 2017 [22]. China is the leading apple producer accounting for an estimated $55 \%$ of total production output [23]. South Africa is the largest producer and exporter of apples in Africa [13] and the continent (Africa) has become the dominant importer (2010-2015) of South African apples. Within the continent, West Africa is the major destination of apples from South Africa at 43\% in 2015 and Nigeria accounted for more than half (62\%) of the imports [24].

As reported by DAFF [24], Nigeria (with a population of about 190 million and still growing), has a huge demand for the fruit as 431 to 55,395 tons of apples were imported from South Africa between 2010 and 2015. The continual increases in the volume of imports of apples into Nigeria shows that there is a great market demand for the fruit and establishes apple fruit production as a potential money-spinning agribusiness venture. However, the apple growers are faced with a lot of constraints which if left unattended to might stall the benefits that would otherwise accrue to them as well as the positive ripple effect on the nation at large. Hence, this research was carried out as a baseline study of growers' constraints in the production of apple in Plateau State, Nigeria. The specific objectives of the study are to: determine the constraints faced by growers in the local production of apples in Plateau State; and to ascertain the felt needs of apple growers in the State.

"Methodology" section is the methodology of the study and contains information on the area of the study, population of the study, sampling procedure and sample size as well as instruments for data collection. "Results and discussion" section presents the results and discussion of the study and findings are reported in the following headings namely; Socio-demographic characteristics of apple growers, enterprise characteristics of apple growers, apple production output, constraints faced by apple growers, income of apple growers, report of the focus group discussion (FGD), on the constraints of apple production, Problem Tree Analysis, needs assessment as well as the priority needs assessment of growers according to local government areas. This section is replete with, figures and tables to further buttress the discussion. The paper culminates in "Summary conclusion and recommendation" section which presents the summary, conclusion, and recommendation of the study.

Due to the dearth of empirical data on apple production in Nigeria, this baseline study is important as it bridges the information gap and serve as a benchmark for further studies going forward. It also provides data that will enable researchers conduct assessment studies and help measure the impact of future interventions in this area of research.

\section{Methodology \\ Area of study}

The study was carried out in Plateau State which is located in Nigeria's middle belt and has an area of $26,899 \mathrm{~km}^{2}$. The State has an estimated population of 3,178,712 (2006 Census) and is bounded by Bauchi to the North-East, Kaduna to the Northwest, Nasarawa to the Southwest and Taraba to the South East. It is located between latitude $9^{\circ} 53^{\prime} 47.4972 \mathrm{~N}$ and longitude $8^{\circ} 51^{\prime}$ $29.9916 \mathrm{E}$. The State is named after the picturesque Jos Plateau, a mountainous area in the north of the State with captivating rock formations. Bare rocks are scattered across the grasslands, which cover the plateau. The altitude ranges from around $1200 \mathrm{~m}$ (about 4000 feet) to a peak of $1829 \mathrm{~m}$ above sea level in the Shere Hills range near Jos.

Though situated in the tropical zone, a higher altitude means that Plateau State has a near temperate (or subtropical) climate with an average temperature of between 18 and $22{ }^{\circ} \mathrm{C}$. Harmattan winds cause the coldest weather between December and February. The warmest temperatures usually occur in the dry season months of March and April. The mean annual rainfall varies from $131.75 \mathrm{~cm}$ (52 in) in the southern part to $146 \mathrm{~cm}$ (57 in) on the Plateau. The highest rainfall is recorded during the wet season months of July and August. The Jos Plateau makes it the source of many rivers in northern Nigeria including the Kaduna, Gongola, Hadejia and Yobe rivers.

Plateau State is an agrarian state and due to its cold weather and flat topography, the State is ranked among the best areas for cultivating major crops (such as rice, wheat, yam, etc.) and raising livestock (such as cattle, sheep, goat, chicken, etc.) in Nigeria. Fishing activities are also carried out here especially around Qua'an-PanShendam axis. The State is inhabited by different ethnic groups, but the dominant ones are the Berom in the northern zone, Mwaghavul and Ngas in the Central Zone, and the Taroh and Goemai in the southern zone. There are settlers such as the Hausa, Fulani, Igbo, Yoruba, etc. The State has great potentials for tourism and agriculture, especially the commercial production of temperate fruits such as apple, strawberry plum, peach, etc. 
Apple production in the State dates back to the arrival of European settlers who endeavoured to cultivate the species they produced and consumed back home. Hence, efforts geared towards apple production has been ongoing for a long period of time spanning over a century. However, due to several constraining factors the enterprise is still largely underdeveloped in the State. The apple growers comprise mainly of small-scale growers dwelling in various Local Government Areas in the State including Jos South, Jos North, Barki Ladi, Riyom, etc. Plateau State has the potential of apple production all year round and the growing demand from markets in Nigeria including supermarkets, processing industries, hotels, etc., shows that there is a need to ascertain and address the constraints that apple growers are faced with to promote continuous production as well as improve on the production systems through adaptive research and extension services.

\section{Population of the study}

The population of the study comprised all apple growers in Plateau State.

\section{Sampling procedure and sample size}

A multi-stage sampling procedure (comprising purposive, snowball and total sampling) was used to select the respondents for this study. Plateau State has 17 local government areas out of which four local government areas namely Jos South, Jos North, Barki Ladi and Riyom were purposively selected because of the prevalence of apple growers in these areas (Stakeholders, Apple Growers Association of Nigeria; Pers. Comm.). Having a single apple tree (rootstock, grafted plant, or a fruiting tree) qualifies one as an apple grower [25]. Furthermore, the snowball sampling technique was used to achieve an enumeration of apple growers in the study area because many of them were not officially registered and they were dispersed across different locations. The snowball sampling was necessitated by the fact that the Apple Growers Association of Nigeria (AGAN) was still in its formative stage, hence, they did not yet have a comprehensive list of apple growers in the study area. This was because, though apple production on the Plateau has been ongoing for a relatively long period of time spanning many decades, the apple growers have, overtime, encountered significant constraints in their enterprise leading to a major decline in the number of growers, total area of land used for apple cultivation (and consequently total yield) as well as a lack of commitment to AGAN. After the enumeration, a total of 30 apple growers were enlisted and all of them participated in the study (total sampling).

\section{Instruments for data collection}

The study used primary and secondary data. The primary data were collected using both qualitative (participant observation (PO), focus group discussion (FDG) and indepth interview (IDI)) and quantitative (survey) methods to meet the objectives of the study while the secondary data were obtained by reviewing textbooks, articles, and other relevant literatures. The instrument for data collection was validated by experts in the Department of Agricultural Extension and Rural Development, University of Ibadan, after reviewing the content side by side the objectives of the study.

Participant observation (also commonly called direct observation or direct field observation) means that the researcher becomes both a participant and an observer. It is the first participatory research method used by social scientists especially anthropologists who lived with people of various cultural backgrounds to gain an insider's perspective of their way of life [26]. This is very useful as it helps to properly comprehend the local situations, events, activities, and views of the people. It requires a long period of time and therefore is seldom fully utilised; nonetheless, it affords one the opportunity to invest time to really know people by interacting with them to gain their perspectives on any given subject [26].

In the study, direct observations were carried out for a period spanning about 4 weeks. During this time, snowball visits were made, apple growers were enlisted, relationships were established, firsthand observations of apple orchards were done, photos were captured, questions and discussions ensued, and complaints were filed by the apple growers to relevant authorities/stakeholders for their assistance.

FGD is used for studying ideas in a group context. Usually, it involves a group discussion of 6-12 persons who share similar backgrounds or characteristics that are meaningful from the research perspective [26]. However, the use of mini groups (comprising 3-4 participants) is gaining widespread acceptance because it gives all participants enough time and opportunity to share. A general rule of the thumb is that the more experience and knowledge the participants have on the given subject, the smaller the group could be [27]. The use of two participants may not be popular, but has been used previously by researchers especially in situations wherein it is warranted [28-31]. In this study, the dispersed spatial distribution of participants coupled with the insecurity threat (posed by ethno-communal clashes and Boko Haram insurgency) in Plateau State and environs affected logistics for the FGDs. Consequently, mini groups comprising two participants were used for the study. The FGD with apple growers in Plateau State was held for a duration of time spanning 
about 4 weeks, i.e. from 10th May 2017 to 5th June 2017. The discussants were made up of both men and women. A total of five FGDs comprising two participants each were held. One FGD was held in Jos North, Barki Ladi and Riyom, respectively. While two FGDs were held in Jos South. The FGDs were used in combination with IDIs in a complementary way such that triangulation of findings was possible. According to [32], an FGD can be used to comment on the results of individual interviews and vice-versa.

During the FGDs, participatory tools were utilised, and Problem Tree Analysis was one of such tools. Olawoye [33] describes problem tree as a participatory tool that enables the participants to understand effects of a problem in terms of the causes and thereby proffer solutions or activities to overcome the problem. Paired Needs Priority Ranking (PNPR) was another important participatory tool that was utilised in the study. PNPR is used for effectively carrying out a needs assessment activity. It entails asking the participants to state what they perceive as their most pressing needs. These pressing needs are then put into a matrix-type format so that they form the row and column headings. The participants are then asked (as a group), to prioritise their needs [34]. During the FGDs, this exercise was carried out with apple growers in Jos South, Jos North, Riyom and Barki Ladi local government areas, respectively.

With properly selected key informants, IDI is an important way to get the needed information. Persons to be interviewed must have the required information and are usually questioned about issues that are of relevance to the researcher [26].

In the study, key informants comprised those who had a great wealth of experience about apple production in the State. They were asked questions from carefully designed interview schedules on matters of central importance to the research. Most of the questions were open-ended to give the informants the opportunity to pursue issues in more depth. Furthermore, due to the baseline orientation of the study, all the respondents were interviewed to glean as much information as possible.

Survey was conducted using a structured questionnaire in the form of interview schedule. A list of possible constraints that apple growers are faced with as compiled from relevant literatures were presented to the respondents and measured using a 3-point scale. Major Constraint (=2); Minor Constraint $(=1)$; Not a Constraint $(=0)$. The mean score was ascertained and used as a benchmark score for ranking the constraints (from first to last) in order of severity. It is noteworthy that the apple growers were also allowed to indicate other constraints
Table 1 Socio-economic characteristics of apple growers in Plateau State

\begin{tabular}{|c|c|c|}
\hline Characteristics & Percent & Mean (SD) \\
\hline Age & & $51( \pm 13)$ \\
\hline $32-38$ & 56.7 & \\
\hline $39-63$ & 23.3 & \\
\hline Above 64 & 20.0 & \\
\hline \multicolumn{3}{|l|}{ Sex } \\
\hline Female & 23.0 & \\
\hline Male & 77.0 & \\
\hline \multicolumn{3}{|l|}{ Marital status } \\
\hline Married & 90 & \\
\hline Single & 10 & \\
\hline Years of formal education & & $17( \pm 4)$ \\
\hline $06-13$ & 13.3 & \\
\hline $14-20$ & 73.3 & \\
\hline $14-21$ & 13.3 & \\
\hline \multicolumn{3}{|l|}{ Occupation } \\
\hline Farming & 46.7 & \\
\hline Personal businesses & 16.7 & \\
\hline Civil service & 13.3 & \\
\hline Others & 23.4 & \\
\hline \multicolumn{3}{|c|}{ Apple production as a major occupation } \\
\hline Yes & 7.0 & \\
\hline No & 93.0 & \\
\hline \multicolumn{3}{|l|}{ Local government area } \\
\hline Jos South & 64.0 & \\
\hline Jos North & 10.0 & \\
\hline Barki Ladi & 13.0 & \\
\hline Riyom & 13.0 & \\
\hline
\end{tabular}

Source: Field survey, 2017

they were faced with, but which were not listed in the survey instrument.

\section{Results and discussion}

Socio-economic characteristics of apple growers

The age distribution in Table 1 shows that over half (56.7\%) of the respondents were between the age bracket of $39-63$ years, $23.3 \%$ were between $32-38$ years while the remaining $(20.0 \%)$ of the respondents were above 64 years. The minimum and maximum ages were 32 and 75 years, respectively, while the mean age was $51( \pm 13)$ years. This implies that majority of the respondents in the study area were adults who were able and energetic enough to carry out the tasking cultural practices (farm operations) associated with apple production in the tropics and particularly in Plateau State. 
This finding is not far-flung from the report of [25] who posited that the mean age of apple producers in the Chencha District of Southern Ethiopia is 46.69 years.

The sex distribution of respondents according to Table 1, showed that the majority (76.7\%) of the respondents were males while the remaining $(23.3 \%)$ were females. The finding implies that males in the study area were more prominent in apple production than the females probably because apples are perceived as having high commercial value. This is in consonance with the reports of the World Bank [35] that studies in Africa have shown that when a crop is perceived as having commercial value, men are likely to be more involved than women.

The result also corroborates the finding of [36] who posited that in Southern Ethiopia (the Chencha District), $81.2 \%$ of apple producers were males while $18.8 \%$ were females.

Table 1 further reveals that almost all (90.0\%) of the respondents were married. The involvement of more married persons in apple production could be attributed to the fact that they are predisposed to a larger household size which will cater for the intensive labour required in apple production (Dalung, 2017, Pers. Comm.).

The table also indicates that all (100.0\%) of the respondents have had a certain level of formal education. The minimum number of years of formal education was 6 years and the maximum number of years of formal education was 25 years. Furthermore, majority (73.3\%) of respondents had between 14-20 years of formal education while $13.3 \%$ of the respondents had between 6-13 and 21-25 years of formal education, respectively. The mean number of years of formal education is 17 $( \pm 4)$ years. The implication of this result is that all the respondents have been exposed to one form of educational training or the other and are thus better positioned to grasp the technicalities involved with the propagation of apples in the tropics.

One of the key-informants in the In-depth Interview section had this to say:

"The apple fruit is an elitist crop and its production in the tropics requires a certain level of technical know-how".

This finding corroborates the result of [36] who posited that apple growers in Southern Ethiopia (Chencha District of Gamo Gofa Zone), were literates with $66.6 \%$ of them having at least a primary school education.

However, this finding contradicts the report of [25] that over $57.0 \%$ of the sampled apple growers in Chencha District of Southern Ethiopia were illiterates; and that this influenced their rate of adoption of modern agronomic practices especially as it concerns apple production.

The findings as represented in Table 1 also show that $46.7 \%$ of the respondents had farming as their occupation. Other livelihood activities of respondents include business (16.7\%), civil service (13.3\%), teaching, engineering, and retirees (6.7\%, respectively), and then tailoring (3.3\%).

Furthermore, the table reveals that even though $46.7 \%$ of the respondents were farmers by occupation, 93.3\% of the respondents indicated that apple production was not their major occupation. This implies that most of the growers had other crops which they cultivated (mixed cropping) as a means of livelihood while others engaged in mixed farming.

Also, the respondents whose primary occupation was not farming, were engaged in other activities as their primary source of livelihood. One participant in the FGD had this to say:

I am a marketer for a pharmaceutical company but engage in apple production because I have a passion for farming and take farming as a hobby...

Additionally, a participant in the IDI had this to say:

"I work in the civil service...but was fascinated when I saw an apple orchard in the PADP garden of those days and I made up my mind that I too was going to have an apple orchard in my compound..."

The table also shows that most (63.3\%) of the respondents were located in Jos south. Other respondents were from Riyom and Barki Ladi (13.3\%), respectively, as well as Jos North (10.0\%). The fact that Jos South local government area had the highest number of respondents may be attributed to the presence of apple promoting agencies like the erstwhile Plateau Agricultural Development Programme (PADP) demonstration garden and the Agricultural Services Training Centre (ASTC) which still had 16 stands of apple trees in their orchard. According to the FGD that was conducted, some discussants said that they got their planting materials (especially the scion used for budding) from the ASTC while a few others said they got theirs during the time when the PADP garden (which comprised a 5-ha apple orchard) was still operational in the area.

One of the participants in the FGD had this to say:

I got my scion from the apple orchard at the ASTC and then budded on the rootstock which I raised myself. 
Table 2 Enterprise characteristics of apple growers in Plateau State

\begin{tabular}{|c|c|c|c|c|}
\hline Variables & Percentage (\%) & Mean & SD & Median (acres) \\
\hline Farm size (acres) & & 0.34 & 0.63 & 0.13 \\
\hline $0.01-0.19$ & 56.6 & & & \\
\hline $0.20-0.39$ & 26.6 & & & \\
\hline 0.40 and above & 16.7 & & & \\
\hline Number of apple trees & & 59 & 170 & 12 \\
\hline $1-10$ & 50.0 & & & \\
\hline $11-20$ & 20.0 & & & \\
\hline $21-30$ & 13.3 & & & \\
\hline $31-40$ & 3.3 & & & \\
\hline $100-200$ & 10.0 & & & \\
\hline $900-1000$ & 3.3 & & & \\
\hline Years of farming experience (years) & & 15 & 13 & \\
\hline $1-10$ & 56.7 & & & \\
\hline $11-20$ & 20.0 & & & \\
\hline $21-30$ & 13.4 & & & \\
\hline 31 and above & 10.0 & & & \\
\hline \multicolumn{5}{|l|}{ Production system } \\
\hline \multicolumn{5}{|l|}{ Mixed cropping } \\
\hline No & 3.3 & & & \\
\hline Yes & 96.7 & & & \\
\hline \multicolumn{5}{|l|}{ Mixed farming } \\
\hline No & 33.3 & & & \\
\hline Yes & 66.7 & & & \\
\hline \multicolumn{5}{|l|}{ Reasons for apple production } \\
\hline Consumption (C) & 26.7 & & & \\
\hline Marketing (M) & 16.7 & & & \\
\hline$C \& M$ & 46.7 & & & \\
\hline Research/trials & 10.0 & & & \\
\hline Passion/prestige & 13.3 & & & \\
\hline \multicolumn{5}{|l|}{ Produce marketing } \\
\hline \multicolumn{5}{|l|}{ Marketing of apples } \\
\hline No & 70.0 & & & \\
\hline Yes & 30.0 & & & \\
\hline \multicolumn{5}{|l|}{ Marketing of seedlings } \\
\hline No & 46.7 & & & \\
\hline Yes & 53.3 & & & \\
\hline \multicolumn{5}{|l|}{ Marketing channels } \\
\hline \multicolumn{5}{|l|}{ Farm gate } \\
\hline No & 90.0 & & & \\
\hline Yes & 10.0 & & & \\
\hline \multicolumn{5}{|l|}{ Local market } \\
\hline No & 90.0 & & & \\
\hline Yes & 10.0 & & & \\
\hline \multicolumn{5}{|l|}{ Arranged market } \\
\hline No & 96.7 & & & \\
\hline Yes & 3.3 & & & \\
\hline
\end{tabular}


Table 2 (continued)

\begin{tabular}{llll}
\hline Variables & Percentage (\%) & Mean & SD \\
\hline Produce buyers & 96.7 & \\
No & 3.3 & \\
Yes & & \\
Interstate market & 96.7 \\
No & 13.3 \\
Yes & \\
\hline
\end{tabular}

Source: Field Survey, 2017

This is in consonance with the findings of [25] who reported that apple production had been confined in and around Chencha (in the Gamo Highlands of Southwest Ethiopia) which is the location where they were first introduced by the British Protestant Missionaries in the 1950s.

\section{Enterprise characteristics of apple growers}

Table 2 reveals that the mean of the farm size is 0.34 $( \pm 0.63)$ ac while the median is 0.13 ac. The maximum farm size is $2.72 \mathrm{ac}$ and the minimum is $0.01 \mathrm{ac}$. The table also reveals that whereas $26.6 \%$ of respondents had $0.20-0.39 \mathrm{ac}$, a higher proportion (56.6\%) of the respondents cultivated a farm area of $0.01-0.19$ ac for their apple production enterprise. However, some (16.7\%) of the respondents cultivated up to $0.40 \mathrm{ac}$ and above of farm area dedicated to apple production.

This implies that the average farm sizes cultivated by apple producers is small especially when it is compared to the large production potential of the State.

The result is in consonance with the findings of [36] that the farm sizes of apple growers in Ethiopia range from 0.063 to $>2.471$ ac with more $(40.3 \%)$ of the apple growers devoting $0.063-0.63 \mathrm{ac}$ of their land to apple production; and that it was a rarity to find growers with $2.471 \mathrm{ac}$ ( $1 \mathrm{ha}$ ) and above of apple orchard. However, this is markedly different from the findings of [24], that the farm sizes of most apple growers in South Africa is 74.13ac (30 ha).

The table also reveals that whereas $20.0 \%$ and $13.3 \%$ of respondents had 11-20 trees and 21-30 trees, respectively, half $(50.0 \%)$ of the respondents had $1-10$ trees in their apple orchards. However, some $(10.0 \%)$ of the respondents had between 100 and 200 trees while few (3.3\%) had as much as 900-1000 trees in their orchards. The table also shows that the mean number of apple trees owned by the apple growers is $59( \pm 170)$ while the median is 12 apple trees.

Furthermore, the mean number of years of farming experience is $15( \pm 13)$ years and over half $(60.0 \%)$ of the respondents had above 15 years of farming experience.
This implies that a higher proportion of the apple growers have been involved in raising apples for almost two decades and are therefore acquainted with the growth habit of the crop in a tropical climate.

The table also shows that almost all (96.7\%) of the respondents practised mixed cropping. However, over half $(66.7 \%)$ of the respondents also practised mixed farming. The multiple responses indicates that most respondents engaged in more than one system of production. This implies that most respondents did not rely solely on the income from apple production especially since its fruiting is seasonal. Also, in cases of unforeseen mishap like crop failure in the apple enterprise, the growers can fall back on their other crops or on their livestock enterprise.

In addition, the table indicates that almost half (46.7\%) of the respondents went into apple production for the purpose of consumption and marketing. Other reasons for going into apple production as indicated by respondents include research/trials (10.0\%), consumption (26.7\%), marketing (16.7\%) and passion/prestige (13.3\%).

A key informant had this to say:

\section{"Some apple growers are what I call hobby growers because their interest in apple production is to have a few trees in their compounds just so they can show off to others that they are growing apples."}

The multiple responses indicate that most respondents had more than one reason for going into apple production. The findings imply that the respondents were not just interested in consuming the fruit but were also looking forward to some economic benefits and may increase their production scale if the economic returns match their expectations.

Table 2 also reveals that most (76.7\%) of the respondents had never marketed their apples. This implies that most of the respondents were involved in the direct consumption of their apple produce. One of the discussants during the FGD had this to say:

'I've never sold any fruit; as soon as I harvest, I share it out amongst family and friends.' 
Table 3 Distribution of respondents by apple production output per tree per season $(\mathrm{kg})$

\begin{tabular}{|c|c|c|c|c|c|c|}
\hline Variable & Category (kg) & Percentage (\%) & Minimum (kg) & Maximum (kg) & Mean (kg) & SD \\
\hline \multirow[t]{6}{*}{ Production output } & 0.00 & 10.0 & 0.0 & 37.50 & 14.0 & 9.0 \\
\hline & $1.0-10.0$ & 20.0 & & & & \\
\hline & $10.1-20.0$ & 46.7 & & & & \\
\hline & $20.1-30.0$ & 20.0 & & & & \\
\hline & 30.1 and above & 3.3 & & & & \\
\hline & Total & 100.0 & & & & \\
\hline
\end{tabular}

$N=30$

Source: Field Survey, 2017

Furthermore, $10.0 \%$ of the respondents indicated that they sold their apples at the farm gate and local market, respectively. This implies that some of the respondents earned some level of income from their apple production enterprise.

One of the key informants had this to say:

'Some persons who need fresh apples, come to buy apples directly from the farm. However, most of the time, I harvest from the farm and send to the buyers because of the distance of my farm from town. It's only when people are pressed to have fresh apples that they come to the farm to buy directly.

'The Lebanese patronise me a lot. They prefer fresh apples to the imported ones.

However, a minute proportion (3.3\%) of respondents did their sales through produce buyers (middlemen) and arranged markets, respectively.

Arranged market in this context means that both the buyer and apple farmer agree as to when and where the sales of the apples will be done. For example, the buyer could contact the apple farmer for the needed quantity and for an agreed price. Once the terms of the transaction are fulfilled the farmer then transports the apples to the desired location of the buyer.

In addition to the sales of apples, the table indicates that over half $(53.3 \%)$ of the respondents also engaged in the sales of seedlings (grafted/budded plants as well as the bare rootstocks). This implies that the number of respondents engaged in the marketing of seedlings were more than those engaged in the marketing of apples. It also implies that the respondents were currently receiving more income from the marketing of seedlings than from the marketing of apples.

This is in consonance with the finding of [37] that in southwestern Ethiopia (until recently) more apple growers were involved in the multiplication of grafted seedlings than in establishing their own apple orchards.

The table also reveals that a small proportion (13.3\%) of the respondents indicated that they utilised the interstate
Table 4 Categorisation of respondents by level of apple production output per season $(\mathrm{kg})$

\begin{tabular}{lcclll}
\hline $\begin{array}{l}\text { Level of } \\
\text { production }\end{array}$ & $\begin{array}{l}\text { Percentage } \\
\text { (\%) }\end{array}$ & Minimum & Maximum & Mean & SD \\
\hline $\begin{array}{l}\text { Low produc- } \\
\text { tion }\end{array}$ & 26.7 & 0.0 & 37.5 & 14.0 & 9.0 \\
$\begin{array}{l}\text { Average pro- } \\
\text { duction }\end{array}$ & 50.0 & & & \\
High produc- & 23.3 & & & \\
tion & & & & \\
Total & 100.0 & & & \\
\hline$N=30$ &
\end{tabular}

channel for the marketing of their produce (both apples and seedlings.) This implies that locally produced apples were also being marketed in other states outside of the Plateau. One of the key informants had this to say:

"I usually take my apples to trade fairs as well as supermarkets. There is a supermarket in Lagos that usually orders for our apples and so we select, package and send to them"

\section{Apple production output}

Table 3 reveals that the minimum and maximum seasonal production output per tree is $0.0 \mathrm{~kg}$ and $37.50 \mathrm{~kg}$ (which is equivalent to a yield potential of 41 metric tons per hectare (MT/ha) at a spacing of $3 \mathrm{~m}$ by $3 \mathrm{~m}$ ), respectively. Furthermore, the mean apple production output per tree is $14 \mathrm{~kg}(15 \mathrm{MT} / \mathrm{ha}$ at $3 \mathrm{~m}$ by $3 \mathrm{~m})$.

This is not far-flung from the findings of [10], who posited that an average yield of $7.5-12.5 \mathrm{~kg}$ per tree was obtained from 3-year-old apple trees during trials in $\mathrm{Pla}$ teau State, Nigeria.

However, this contradicts the findings of [25] who posited that an average yield of $24 \mathrm{~kg}$ per apple tree was obtained in one harvesting season by apple growers in Ethiopia. 
Table 5 Distribution of respondents by constraints faced in apple production

\begin{tabular}{|c|c|c|c|c|c|c|}
\hline $\mathrm{S} / \mathrm{N}$ & Constraints faced by apple growers & $\begin{array}{l}\text { Major constraints } \\
(\%)\end{array}$ & $\begin{array}{l}\text { Minor constraints } \\
(\%)\end{array}$ & $\begin{array}{l}\text { Not a constraint } \\
(\%)\end{array}$ & Mean & Rank \\
\hline 1 & Ineffective extension services & 96.7 & 0.0 & 3.3 & $1.93^{* *}$ & $1 s t$ \\
\hline 2 & Inadequate finance and credit facilities & 93.3 & 3.3 & 3.3 & $1.90^{* *}$ & 2nd \\
\hline 3 & High cost of farm input & 86.7 & 10.0 & 3.3 & $1.83^{* *}$ & $3 r d$ \\
\hline 4 & Capital intensiveness of the enterprise & 83.3 & 13.3 & 3.3 & $1.80^{* *}$ & 4th \\
\hline 5 & Lack of support from government & 83.3 & 13.3 & 3.3 & $1.80^{* *}$ & 4th \\
\hline 6 & $\begin{array}{l}\text { Scarcity of farm inputs like quality apple scions } \\
\text { and rootstocks }\end{array}$ & 83.3 & 13.3 & 3.3 & $1.80^{* *}$ & 4th \\
\hline 7 & Invasion of Fulani herdsmen & 70.0 & 26.7 & 3.3 & $1.67^{*}$ & 7th \\
\hline 8 & Pest and disease infestation & 50 & 50 & 0.0 & $1.50^{*}$ & 8th \\
\hline 9 & Incessant communal conflict & 60.0 & 23.3 & 16.7 & $1.43^{*}$ & 9th \\
\hline 10 & Land tenure problem & 43.3 & 33.3 & 23.3 & $1.20^{*}$ & 10th \\
\hline 11 & Climate change & 30 & 50 & 20 & $1.10^{*}$ & 11th \\
\hline 12 & Poor soil fertility & 20.0 & 66.7 & 13.3 & 1.07 & 12th \\
\hline 13 & The production of apples is stressful & 23.3 & 43.3 & 33.3 & 0.90 & 13th \\
\hline 14 & Shortage of farm labour & 13.3 & 46.7 & 40.0 & 0.73 & 14th \\
\hline 15 & Perishability of the crop & 3.3 & 3.3 & 93.3 & 0.10 & 15 th \\
\hline 16 & Inadequate storage facilities & 3.3 & 3.3 & 93.3 & 0.10 & 15 th \\
\hline 17 & Lack of transport facilities & 0.0 & 3.3 & 96.7 & 0.03 & 17th \\
\hline 18 & Glut particularly at the peak of production & 0.0 & 0.0 & 100.0 & 0.00 & 18th \\
\hline 19 & Unavailability of market & 0.0 & 0.0 & 100.0 & 0.00 & 18th \\
\hline
\end{tabular}

Source: Field Survey, 2017

Grand mean $=1.09 ;{ }^{* *}=$ major constraints; ${ }^{*}=$ minor constraints

The table also reveals that almost half $(46.7 \%)$ of the respondents had an average production output ranging between 10.1 and $20.0 \mathrm{~kg}$ per season. Additionally, $20.0 \%$ of respondents had an average seasonal output ranging between $1.0-10$ and $20.1-30.0 \mathrm{~kg}$, respectively. However, some (10.0\%) respondents indicated that they are yet to harvest any apple fruits from their orchards. Nevertheless, this does not undermine the fact that few (3.3\%) respondents had a seasonal harvest of over $30 \mathrm{~kg}$ of produce.

Using the mean and standard deviation as a guide, the respondents were categorised into three: poor, average, and high production levels. Table 4 reveals that half $(50.0 \%)$ of the respondents fell within the average production category. Furthermore, $26.7 \%$ and $23.3 \%$ of the respondents fell into the low and high production level categories, respectively. This implies that most of the respondents were able to successfully get their apple trees to fruit moderately using tropical apple culture techniques. However, some of the respondents who practised more intensive management systems were able to achieve better results.

A key informant had this to say:

'The intensive management I give my apple orchard makes it produce better than other notable orchards around.
Table 6 Distribution of respondents according to their income category

\begin{tabular}{llll}
\hline Income category $(\boldsymbol{N})$ & Percentage & Mean $( \pm$ SD) & Median \\
\hline None & 10.0 & $620,133.3$ & 40,000 \\
& & $( \pm 2,499,308.0)$ & \\
$<40,000$ & 43.3 & & \\
$40,001-200,000$ & 26.7 & & \\
$>200,000$ & 20.0 & & \\
\hline
\end{tabular}

Source: Field Survey, 2017

\section{Constraints faced by apple growers}

Table 5 reveals the respondents' percentage distribution and ranks of constraint in order of severity. It shows that ineffective extension services (1.93) ranked first in order of severity, and this was followed by inadequate finance/ credit facilities (1.90) and high cost of farm inputs (1.83) ranking 2nd and 3rd, respectively. Additionally, invasion of Fulani herdsmen (1.67) and incessant communal conflicts (1.43) were considered as minor constraints to apple production by the respondents. This must have been due to the fact that majority of the apple growers had their orchards within enclosed areas (especially within their residential compounds); hence were not adversely affected by the activities of Fulani herdsmen and the incessant communal conflicts that happened in 
Table 7 Potential annual income from apple production

\begin{tabular}{lc}
\hline Variables & Derived estimates \\
\hline Average quantity of apple imports (2011-2015) in tons & $28,212.6$ tons \\
Average quantity of apple imports (2011-2015) in kg & $28,212,600 \mathrm{~kg}$ \\
Average weight of South African apples & $150 \mathrm{~g}(\mathrm{or} 0.15 \mathrm{~kg})$ \\
Average number of fruits imported into Nigeria annually & $188,084,000$ fruits \\
Average price per apple fruit in Nigeria & $100 \mathrm{Naira}$ \\
Monetary value of apple imports in Nigeria & $18,808,400,000 \mathrm{Naira}$ \\
Mean income of apple farmers & $620,133.3$ \\
Percentage of mean income to potential income per annum & $0.003 \%$ \\
Income gap to be covered & $99.997 \%$ \\
Verdict (possibility of huge income increment) & Yes \\
\hline
\end{tabular}

Source: Estimated from South Africa Marketing Directorate Report on Apple Production, 2016

the State. Furthermore, respondents indicated that glut particularly at the peak of production (0.00) and unavailability of market $(0.00)$ were not considered as constraints. These findings imply that the respondents were in dire need of training and look to extension agents to help bridge the gap to obtain the optimal level of production output attainable in the tropics.

\section{Annual income from apple production}

Table 6 shows that a higher proportion (43.3\%) of apple growers realised less than $\mathrm{N} 40,000$ per annum from apple production. The mean annual farm income from apple production was N620,133.30 ( $\pm 2,499,308.0)$. This translates to N3333.33 income made by the apple growers per month from apple production. This amount is far lower than the current monthly minimum wage being paid by the Nigerian Civil Service and the average private sector employer of labour for people with qualifications like the National Diploma (ND), Nigeria Certificate in Education (NCE), Higher National Diploma (HND), Bachelors (B.A or B.Sc.), etc.

The yearly mean income from apple production is very low and unappreciable when compared with what is obtainable from the production of other crops in Nigeria. Oyibo [38] found that in the Niger Delta region of Nigeria, the mean yearly income realised by farmers engaged in the production of sweet potato, cassava, yam, maize, plantain, and okra was 1,327,723; 981,603; 325,328; 231,147; 794,857 and 1,043,126, respectively. The low income realised by farmers may serve as a disincentive to continue with apple production if the problems are not addressed.

Table 7 shows the potential annual income from apple production in Nigeria. The income potential was calculated from the production deficit occasioned by the market forces of demand and supply.
The production deficit was estimated by analysing the import reports of apples into Nigeria. Due to a dearth of data on apple production in Nigeria, import estimates were gotten from the South African Marketing Directorate which documents the volume and value of South African apple exports, and the data are disaggregated by country. This is justified because Africa absorbs the lion share of South African apple exports and Nigeria accounts for the highest percentage of total apple imports in the region [24].

The table shows that there is an enormous disparity between the income per annum of apple farmers and the potential income that can be earned, owing to a large, ready, and highly unsaturated apple market. A minuscule proportion $(0.003 \%)$ of the entire income pie is what growers are receiving and the huge demand which is almost entirely met by imports presents an opportunity for investment and increased income per annum. These figures are conservative projections and given that apples are also imported from other countries (other than South Africa), real life scenarios may highlight a wider production deficit and consequently, a higher income potential for apple growers.

\section{Report of the focused group discussion (FGD) on the constraints of apple production}

FGD is used for studying ideas in a group context. The use of two participants (particularly when warranted) has been used previously by researchers [27]. The focus group discussions with apple growers in Plateau State was held for a duration of time spanning about 4 weeks, i.e. from 10th May 2017 to 5th June 2017. The discussants were made up of both men and women. The report of the discussion is presented below.

Discussants itemised a list of constraints that they were confronted with, and they are as follows. 


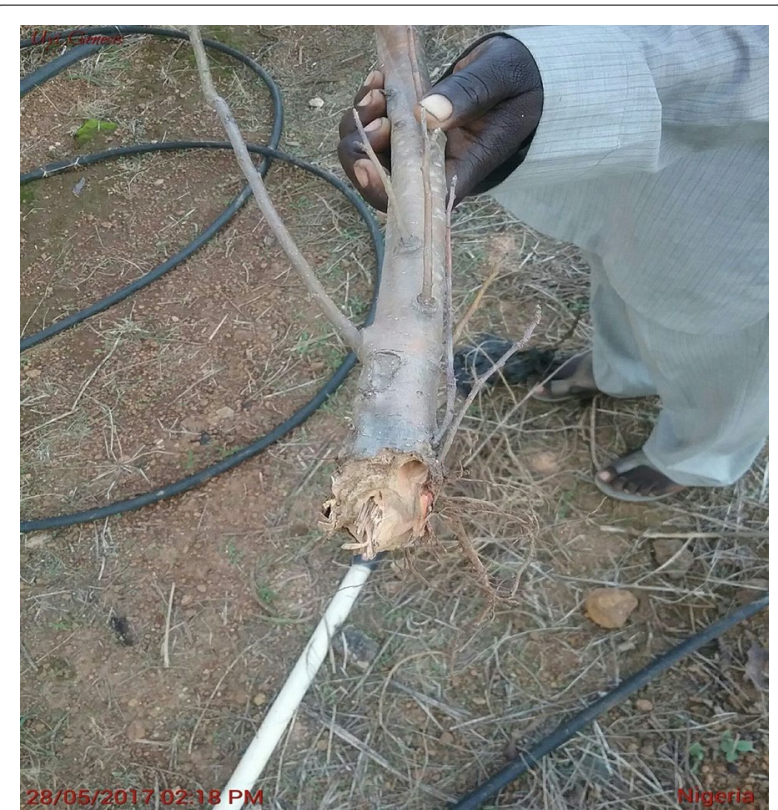

Fig. 1 Remains of an apple tree eaten up by termites in Barki Ladi

\section{Lack of extension services}

Most discussants expressed their displeasure at the fact that they had no professionals to make enquiries from especially because there were lots of information flying around and they were mainly from unofficial sources. Furthermore, they stated that most of the information they got from the internet were targeted at apple producers in the temperate regions and not well suited for them in the tropics; hence, they emphasised the need for locally adapted research and the roles of extension agents in communicating the findings to them.

One of the discussants had this to say:

“.I've never liked to work with government. I prefer working with private research/extension organisations for the development and expansion of my apple production enterprise. The government just makes noise and do nothing..."

\section{Lack of coordinated work}

The discussants pinpointed that there was no coordinated platform for information sharing and execution of planned actions. They also berated the academic system that it was too theory oriented rather than practical based; stating that there was need for them to carry out practical oriented research on apple production. They also said that this aspect was closely tied with effective extension services.

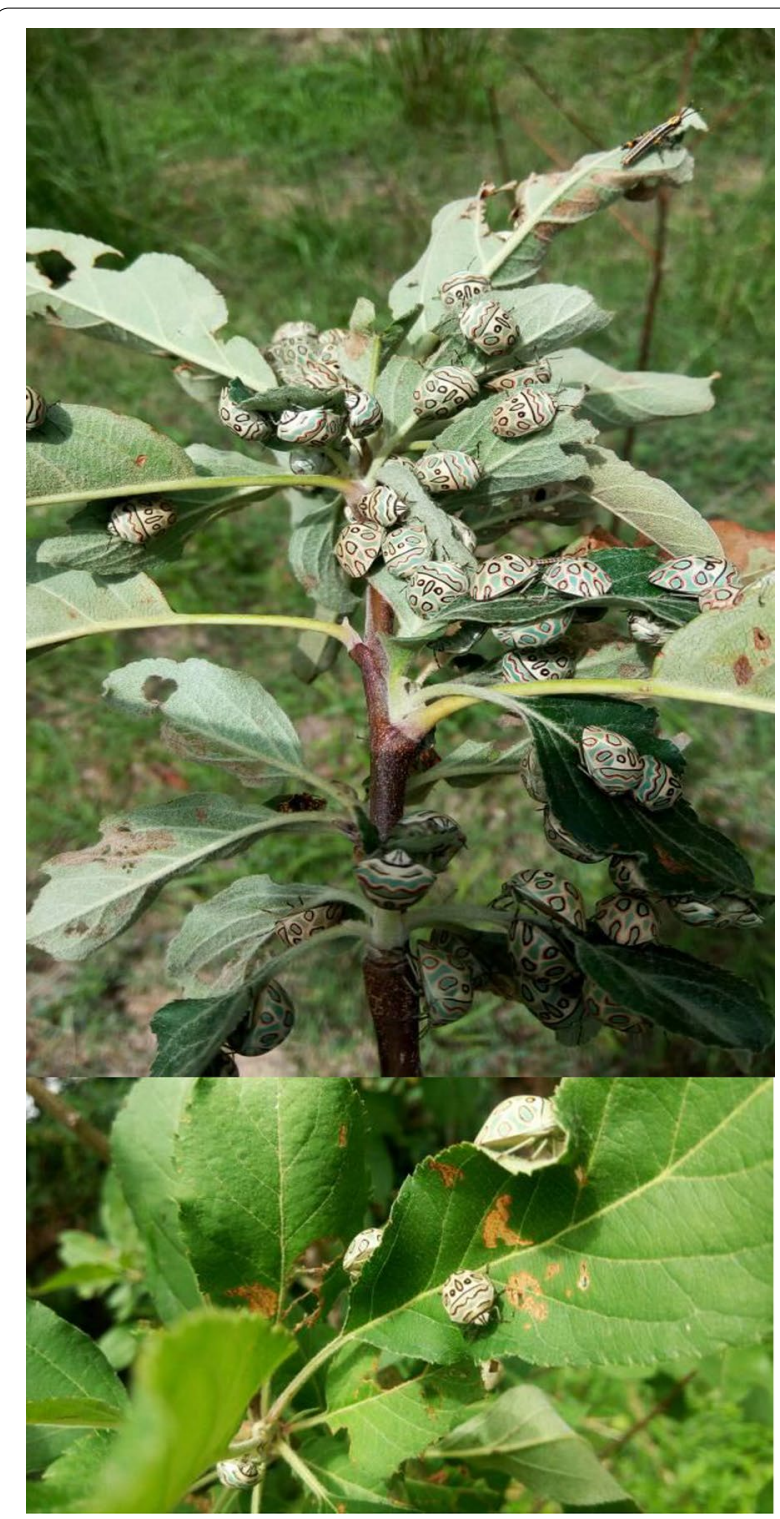

Fig. 2 *An apple pest—Picasso bug (Sphaerocoris annulus) —at an orchard (with 200 stands of apple trees) in Kinat, near Mangu, Plateau State. ${ }^{*}$ NB - Although the Picasso bug is the prominent pest in the plate, it is not responsible for the chewed portions of the apple leaves. This is because the Picasso bug has a piercing and sucking mouth part which focuses on the sap from the apple plant. Therefore, the apple plant in the plate above was attacked by multiple insect pests. The insect pest responsible for the damage on the plant has a biting and chewing mouth part and it is most likely a grasshopper (Zonocerus variegatus) which can be seen at the top right end of the plant in the plate

\section{Pest and disease infestation}

This was reported by most discussants to be a serious matter. Termites were the most significant pest of apples in the State, and this was closely followed by birds. In the 
same vein, dieback disease was said to be the most devastating to apple production in the State. Furthermore, both organic and inorganic methods of addressing termites were prescribed and it entailed the use of neem (Azadirachta indica) extracts and insecticides, respectively (Figs. 1, 2).

"Termites can be addressed both organically and inorganically. Inorganically, insecticides that are suited for termites can be applied. Organically, the extract from Neem (Azadirachta indica); has proven to be very effective. Also, the leaves of the Neem plant can be buried around the apple plants, and this will deter termites. Additionally, the fruits or seeds of the Neem plant can be used as well. These are all proven methods and I've tried them myself. The use of Azadirachta indica is one of the best organic ways of addressing insects on the field. The extracts are sold commercially in some places within the country".

\section{Means of preservation}

Discussants mentioned that most of them cultivated the Anna variety which has an average shelf life of 7-10 days; hence the need for long-term storage/preservation especially when they increase their scale of production. Most of the discussants made it known that they seldom preserved their apple produce since they ate it right away or shared it amongst family and friends. However, some of them accented to preservation by refrigeration.

\section{High cost of seedlings}

This was identified as a major constraint by all discussants. The ordeal of one of the discussants is narrated below:

"I got involved with apples as far back as 1991/1992. An agent with Afri-fruits supplied me at the rate of 300 naira per stand and the stocks were imported from Israel. Gradually it went up to about 1500 naira, then 2000 naira, and then 3000 naira per stand of seedling. The last time we negotiated was in 2015, and I was told that each stand was going to cost about 5000 naira. Indeed, it is the singular most expensive crop in the Nation. Those who buy from us sell for as much as 18,000 to 20,000 in the market and yet people buy it. It is exotic, new and a novelty; therefore, people buy it. But again, when ordering in large quantities, the price per stand will drop down of course. I used to import about 3000 to 5000 seedlings. Of recent, I've not been able to do so because of the current exchange rate of the dollar to the naira. It is outrageous and I just can't do it espe- cially because nobody is willing to commit himself by paying upfront."

\section{Climate change}

Some discussants opined that climate change was an issue, and that back then in the 1980s when PADP had a demonstration garden with a thriving apple orchard, the temperatures were cooler on the Plateau; hence favourable for apple production: stating further that, the current climatic conditions may not be as favourable for apple production as before. However, majority of discussants did not share in the opinion and were convinced that climate change had not affected apple production on the Plateau.

Some discussants had this to say:

"I don't share that opinion with them at all... I was told that apples will not thrive well down here and behold I'm here growing apples. I travelled down to Israel and those who are experts in the field told me that our climate was fine for the crop. I don't know what the climate is going to be like tomorrow, but I think the crop thrives well in our current climate. Hence climate is a minor constraint..."

".. despite the fact that people say that Jos is not as cold as it used to be, I still think that it doesn't affect apple production in the state... because we have sold seedlings to clients in places like Minna (in Niger State) and Bauchi (in Bauchi State) and we were told that the apples are doing fine despite the heat, hence I think climate change is not a major problem in Jos, Plateau State, as far as apple production is concerned".

\section{Poor soil fertility}

Discussants reached a consensus that this was also a major issue especially because soils in the State had been adversely affected by the mining activities of the past. They stated that the soils are mainly acidic and that a lot of money had to be spent to address the issue. Therefore, it was deemed a constraint.

A discussant had this to say:

"The farm area in my compound was composed basically of laterite soil and I had to get in nine tippers (big trailer loads) of rich soil to make the land suitable for cultivation."

\section{Others}

Other constraints highlighted by respondents included: incessant communal conflict (especially for those who 


\begin{tabular}{|c|c|c|c|c|c|c|c|c|}
\hline & $\begin{array}{l}\text { Ext } \\
\text { Services }\end{array}$ & $\begin{array}{l}\text { Farm } \\
\text { inputs }\end{array}$ & $\begin{array}{l}\text { Credit } \\
\text { Facilities }\end{array}$ & $\begin{array}{l}\text { Suitable } \\
\text { Land }\end{array}$ & $\begin{array}{l}\text { Subsidized } \\
\text { seedlings }\end{array}$ & $\begin{array}{l}\text { Pest \& } \\
\text { Disease } \\
\text { Control }\end{array}$ & Insurance & $\begin{array}{l}\text { Storage } \\
\text { Facilities }\end{array}$ \\
\hline $\begin{array}{l}\text { Ext } \\
\text { Services }\end{array}$ & & $\begin{array}{l}\text { Ext } \\
\text { Services }\end{array}$ & $\begin{array}{l}\text { Ext } \\
\text { Services }\end{array}$ & $\begin{array}{l}\text { Ext } \\
\text { Services }\end{array}$ & $\begin{array}{l}\text { S. } \\
\text { Seedlings }\end{array}$ & $\begin{array}{l}\text { Ext } \\
\text { Services }\end{array}$ & $\begin{array}{l}\text { Ext } \\
\text { Services }\end{array}$ & $\begin{array}{l}\text { Ext } \\
\text { Services }\end{array}$ \\
\hline $\begin{array}{l}\text { Farm } \\
\text { inputs }\end{array}$ & & & $\begin{array}{l}\text { Credit } \\
\text { facilities }\end{array}$ & $\begin{array}{l}\text { Farm } \\
\text { inputs }\end{array}$ & $\begin{array}{l}\text { S. } \\
\text { Seedlings }\end{array}$ & $\begin{array}{l}\text { Pest \& } \\
\text { Disease } \\
\text { control }\end{array}$ & $\begin{array}{l}\text { Farm } \\
\text { inputs }\end{array}$ & $\begin{array}{l}\text { Farm } \\
\text { inputs }\end{array}$ \\
\hline $\begin{array}{l}\text { Credit } \\
\text { Facilities }\end{array}$ & & & & $\begin{array}{l}\text { credit } \\
\text { facilities }\end{array}$ & $\begin{array}{l}\text { S. } \\
\text { Seedlings } \\
\end{array}$ & $\begin{array}{l}\text { credit } \\
\text { facilities }\end{array}$ & $\begin{array}{l}\text { credit } \\
\text { facilities }\end{array}$ & $\begin{array}{l}\text { credit } \\
\text { facilities }\end{array}$ \\
\hline $\begin{array}{l}\text { Suitable } \\
\text { Land }\end{array}$ & & & & & $\begin{array}{l}\text { S. } \\
\text { Seedlings }\end{array}$ & $\begin{array}{l}\text { Pest \& } \\
\text { Disease } \\
\text { control }\end{array}$ & $\begin{array}{l}\text { Suitable } \\
\text { Land }\end{array}$ & $\begin{array}{l}\text { Suitable } \\
\text { Land }\end{array}$ \\
\hline $\begin{array}{l}\text { Subsidized } \\
\text { Seedlings } \\
\end{array}$ & & & & & & $\begin{array}{l}\text { S. } \\
\text { Seedlings }\end{array}$ & $\begin{array}{l}\text { S. } \\
\text { Seedlings } \\
\end{array}$ & $\begin{array}{l}\text { S. } \\
\text { Seedlings }\end{array}$ \\
\hline $\begin{array}{l}\text { Pest \& } \\
\text { Disease } \\
\text { Control }\end{array}$ & & & & & & & $\begin{array}{l}\text { Pest \& } \\
\text { Disease } \\
\text { Control }\end{array}$ & $\begin{array}{l}\text { Pest \& } \\
\text { Disease } \\
\text { Control }\end{array}$ \\
\hline Insurance & & & & & & & & Insurance \\
\hline $\begin{array}{l}\text { Storage } \\
\text { Facilities }\end{array}$ & & & & & & & & \\
\hline
\end{tabular}

Fig. 3 Paired needs ranking results with Jos South apple growers in Plateau State. Source: Field Survey, 2017

have crops outside of fenced premises), insufficient diversity of the apple cultivar base available in the State, unavailability of parent stock, high cost of farm inputs, high cost of farm labour (because of the need to pay for labour especially when production involves organic farming where chemicals are not used), inadequate credit facilities, etc.

\section{Problem Tree Analysis}

During the FGDs, participatory tools were utilised, and Problem Tree Analysis (PTA) was one of such tools. Olawoye [33] describes problem tree as a participatory tool that enables the participants to understand effects of a problem in terms of the causes and thereby proffer solutions or activities to overcome the problem.

Figure 3 illustrates the composite of the results from this exercise, with several groups across the local government areas. The problem given to the participants to analyse was low apple production output. Participants were asked to give causes of low apple production output as the 'root' of the tree and consequences (effects) of low apple production output as the 'fruits' of the tree. The participants viewed lack of extension services, high cost of seedlings, inadequate/inaccessible credit facilities, lack of parent stock, high cost of farm inputs, high labour cost, infestation of pest and diseases, theft/pilfering, lack of market reports, and lack of storage facilities as the causes (roots) of the problem while high dependency ratio, low wages, importation, loss of foreign exchange, collapse of local industry and unemployment as the effects (fruits) of low apple production output. In essence, if the causes of the problem of low production output are not given serious attention, there will be an increased manifestation of the effects in Plateau State and Nigeria at large.

\section{Needs assessment}

This is an effective way of ascertaining the felt needs of groups in any setting. It allows groups to determine their most pressing needs by identifying, pairing, and prioritising the problems they are confronted with [18].

Paired Needs Priority Ranking is an important participatory tool used for effectively carrying out a needs assessment activity. It entails asking the participants to state what they perceive as their most pressing needs. These pressing needs are then put into a matrix-type format so that they form the row and column headings. The participants are then asked (as a group), to prioritise their needs [18]. During the FGDs, this exercise was carried out with apple growers in Jos South, Jos North, Riyom and Barki Ladi local government areas, respectively.

Figure 3 shows the result of the exercise with apple growers in Jos South local government area of Plateau State. When the count (for the number of times each need was selected as the priority between a pair of needs) was made, it was discovered that subsidised seedlings (i.e. reduction in the high cost of quality seedlings of different apple varieties suited for the tropics), was chosen seven times, making it the highest-ranking priority need 
Table 8 Priority needs ranking* by local government areas in Plateau State

\begin{tabular}{|c|c|c|c|c|}
\hline Selected need & Jos South & Jos North & Riyom & Barki Ladi \\
\hline Extension services & 2nd & 2nd & 2nd & $3^{\text {rd }}$ \\
\hline Subsidised farm inputs (like, fungicides, fertilisers, etc.) & 5 th & - & 4th & \\
\hline Credit facilities & $3 r d$ & - & 5 th & 2nd \\
\hline Large acreage of suitable land & 7 th & 5 th & - & 4 th \\
\hline Irrigation facilities & 6 th & $3 r d$ & - & 5 th \\
\hline $\begin{array}{l}\text { Subsidised quality seedlings of different varieties suited for the } \\
\text { tropics }\end{array}$ & $1 s t$ & $1 s t$ & $1 s t$ & $1 s t$ \\
\hline Pest and disease control & 4 th & 4th & $3 r d$ & - \\
\hline Insurance against pilfering & - & 7 th & - & - \\
\hline Storage and preservation facilities & - & 6th & - & - \\
\hline Parent stock & 8th & - & - & - \\
\hline Market reports & 9th & - & - & - \\
\hline
\end{tabular}

Source: Field Survey, 2017

${ }^{*}$ Rankings in the table means: $1 \mathrm{st}=$ most important; $2 \mathrm{nd}=$ second most important, and so on

for the apple growers on the Plateau. Extension services, i.e. the roles of extension agents in researching (or liaising with research institutions), demonstrating, training, and disseminating information about best practices in apple growing as it applies to their local environment was selected six times making it the next highest priority of the group. This is followed by credit facilities with five selections as the 3rd priority need, while pest and disease control is the 4th priority need with four selections. The need for subsidised farm inputs (i.e. fungicides, pesticides, fertilisers, etc.), irrigation facilities, large acreage of suitable land and parent stock ranked 5th, 6th, 7th, and 8th, respectively, in the group's priority need. The least priority of the group was having market reports.

\section{Priority needs ranking of growers according to local government areas}

The summary of the findings of the paired needs ranking exercises conducted during the FGDs is presented in Table 2. From the results of the Paired Needs Priority Ranking, the differences in the priorities of the apple growers across the various local government areas can be readily seen.

The need of subsidising the cost of different varieties of apple seedlings that are suited for the tropics ranks first among apple growers across the various local government areas. However, there are obvious differences in the order of priority for other needs, e.g., the need for extension services ranks 3rd with apple growers in Barki Ladi, whereas for other apple growers in the various local governments, it ranks 2nd. It therefore means that apple growers in Barki Ladi prioritised their need for credit facilities over their need for extension services (Table 8).

\section{Summary conclusion and recommendation Summary}

Apple (Malus domestica) is a fruit tree that grows well in temperate climate zones. However, apple production in strictly tropical zones, such as Nigeria may well seem an impossible venture to whoever is unfamiliar with the scientific advancements of recent years in certain tropical regions. New scientific discoveries have birthed an increasing trend of producing temperate fruits in the tropics and subtropics. With the increasing trend of growing temperate fruits in the strictly tropical regions, there has also been a gradual increase in the number of growers who are currently engaged in the cultivation of apples in Plateau State, Nigeria. The continual increases in the volume of apple fruit imports into Nigeria (Fig. 4) shows that there is a great market demand for the fruit and establishes apple fruit production as a potential money-spinning agribusiness venture. However, the apple growers are faced with a lot of constraints which if left unattended to might stall the benefits that would otherwise accrue to them as well as the positive ripple effect on Nigeria at large. Hence, this project research was carried out with the objective of conducting a baseline study on the constraints of apple fruit production in Plateau State, Nigeria, with a view to providing suggestions and solutions to these constraints.

\section{Conclusion}

Ineffective extension services, inadequate finance/credit facilities and high cost of farm inputs (particularly of apple seedlings) ranked 1st, 2nd, and 3rd. respectively, as the most severe constraints faced by respondents in apple production. Pest and disease infestation was also 


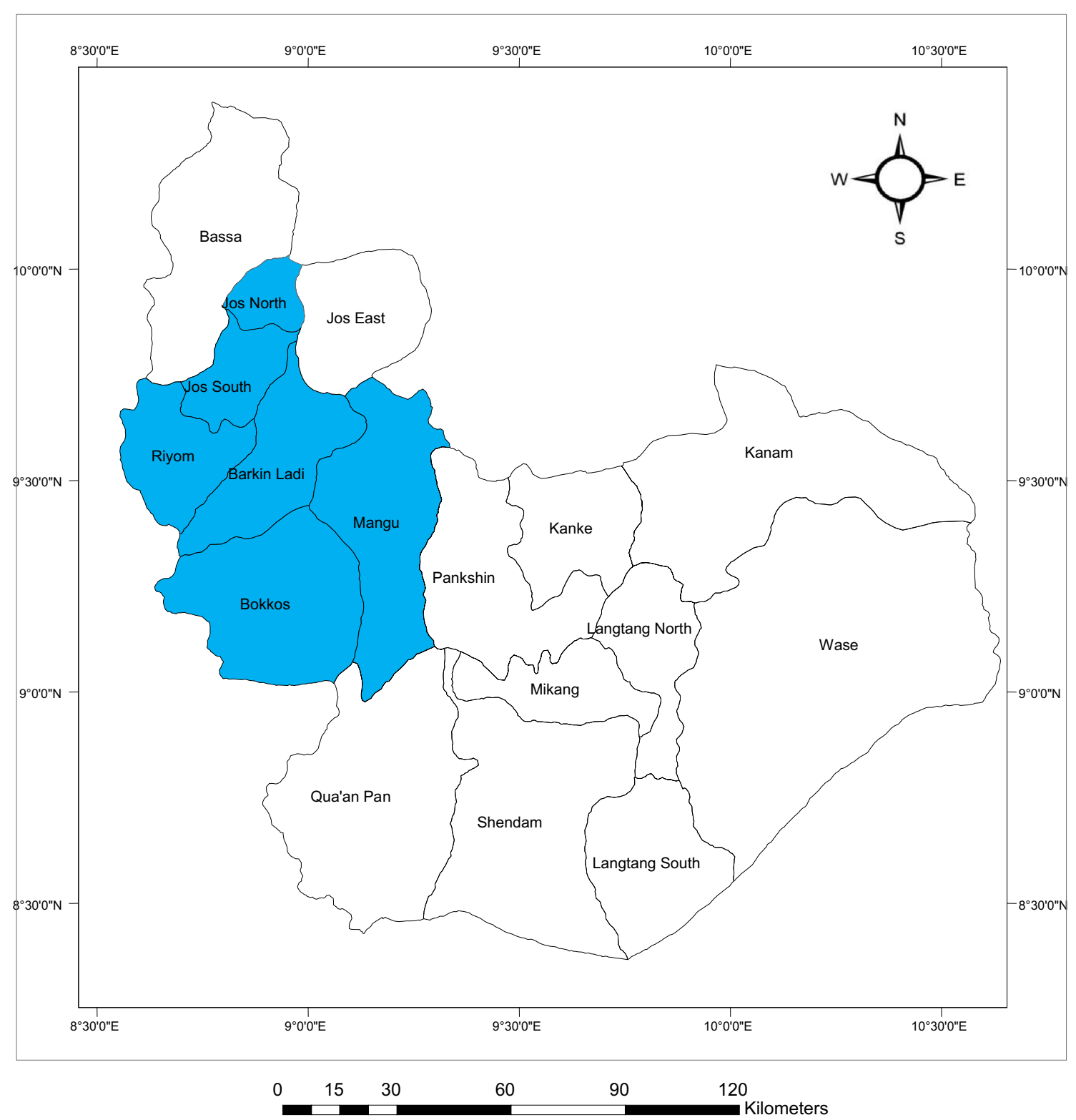

\section{Legend}

Local Government Areas where apple is cultivated

Fig. 4 Plateau State showing the local government areas (LGAs) where apple production is predominant in the State. Source: GIS Lab, University of Jos 


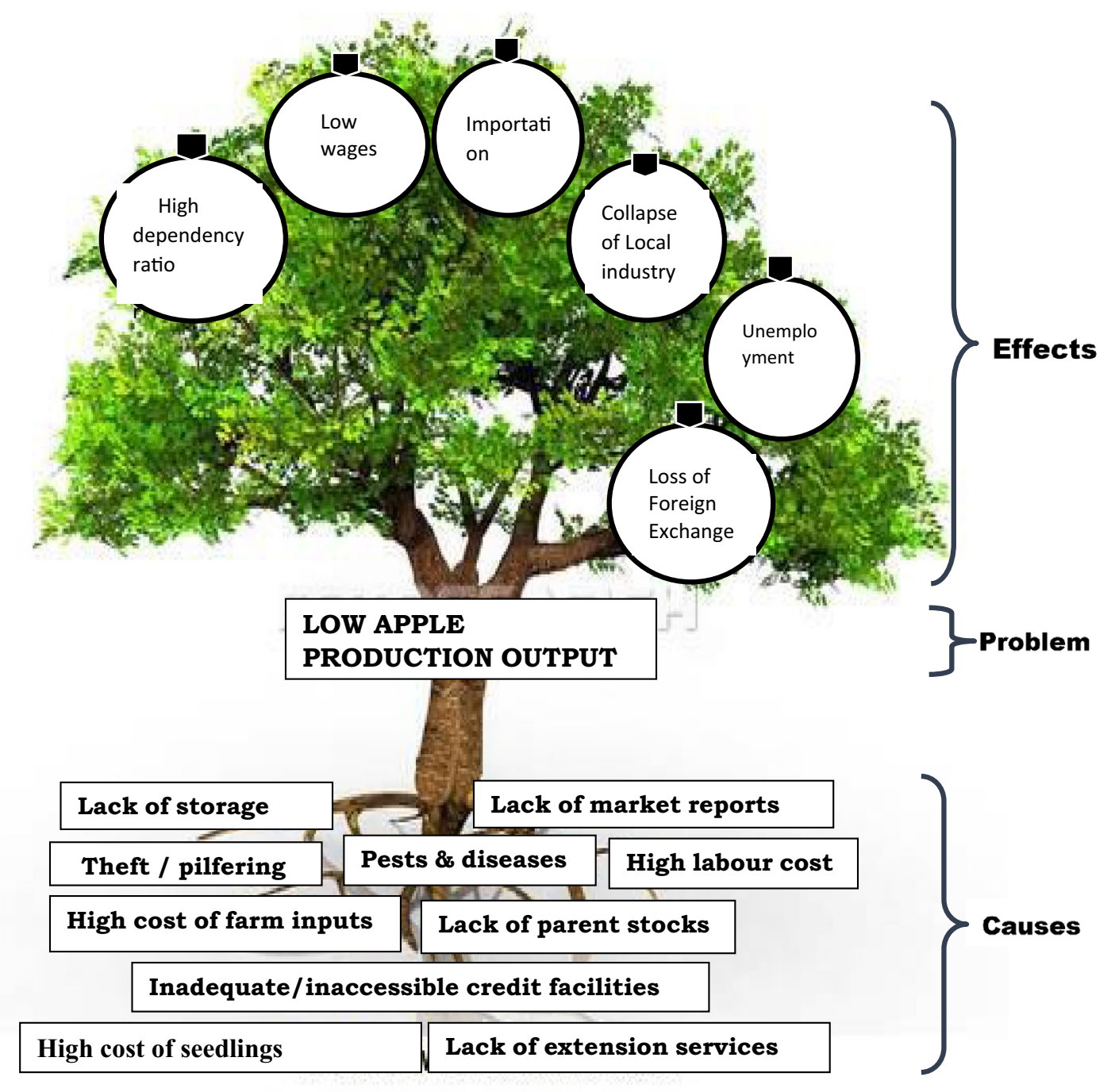

Fig. 5 A Problem Tree Analysis of low apple production output in Plateau State, Nigeria. Source: Field Survey, 2017

viewed as a constraint. Termites and birds were the most destructive pests of apples while dieback disease was the most devastating to apple production in the State (Fig. 5).

\section{Recommendations}

1. The most severe constraints faced by growers are lack of extension services, inadequate finance/credit facilities, and high cost of farm inputs (particularly seedlings). Therefore, the following are recommended:

- The apple growers should be assisted with extension agents to help them with practical knowledge and applicable cultural practices required for apple production in the tropics (particularly in Plateau State); hence extension agents should be trained in this regard. This will also address the issue of pest and diseases as extension agents will guide apple growers on the best practices to follow to solve this constraint.

- Furthermore, credit facilities should be made available and accessible for apple production especially since it is highly capital intensive. Additionally, farm inputs (especially the apple seedlings) should be subsidised to encourage growers to expand their scale of production. Currently an apple seedling (grafted plant comprising a rootstock and scion) cost between 10,000-20,000 naira (approx. 28-55 
US dollars) per plant depending on the plant's level of maturity at the point of purchase. This is indeed expensive and has hindered growers from expanding their production scale, hence the need for credit facilities and subsidies. This is in consonance with the findings of [1] who reported that grafted apple seedlings which were sold for as much as four thousand Ugandan Shillings (Ush 4000) were viewed as very costly by growers.

- The Apple Growers Association of Nigeria (AGAN) which is still at its formative stage should expedite actions in becoming a full-fledged operational cooperative to wholly assist its members as well as benefit maximally from government programmes and other credit facilities.

\section{Abbreviations}

PAULESI: Pan African University, Life and Earth Sciences Institute; LGAs: Local government areas; FGD: Focused group discussion; PTA: Problem Tree Analysis; PNPR: Paired Needs Priority Ranking; PADP: Plateau Agricultural Development Agency; ASTC: Agricultural Services and Training Centre; UTC: United Trading Company; AGAN: Apple Growers Association of Nigeria.

\section{Acknowledgements}

The authors are grateful to Almighty GOD for the enablement to complete and publish this research which began as an uphill task in the conflict-ridden region of Plateau State, Nigeria.

Indispensable in our pursuit of information about apple production, are the following personalities whom we deeply appreciate; His Royal Highness Da (Dr) Samuel M. Jok (Da Gwom Rei of Riyom), Mai-angwa Bulus Dayura (Maiangwa of Kwallak, Riyom), Mr Muhammed Hassan (Former Director, PADP), Engr. Philip K. Gonap (Programme Manager of the PADP), Engr. Emmanuel Dalung (Chairperson, Apple Growers Association of Nigeria (AGAN)), Hajia (Mrs.) I.L Bashir (National Vice President, All Farmers Association of Nigeria (AFAN)), Dr and Mrs. Ben Omoayena (All Green Farms), Mr. Oscar Fom, (Former Programme Manager, UTC Farms), Mr. lan Kedem (Site Manager, ASTC Vom), Dr (Mrs.) Oyedele (NIHORT), Dr Nuhu Daze (Niret Farms), Mr Christopher Joseph, Mr Austin Ashigidi (Ashigidi Farms Enterprises), Dr. (Mrs.) Deshi (Department of Botany, University of Jos), Profs Ezekiel and Shedrach Best (University of Jos), Mr. Sunday Kumkat, Ms. Keri and all apple growers in Plateau State. Thank you very much for your time despite your busy schedules. A big thank you to Precious E. Adebola who helped with copy editing of the manuscript. We are grateful for your invaluable inputs that has culminated in a better manuscript.

\section{Authors' contributions}

UG conceptualised the study, collected data and drafted the manuscript; AE supervised and revised the manuscript; EA made significant inputs during fieldwork/data collection, data analysis and editorials. All authors read and approved the final manuscript.

\section{Funding}

Not applicable.

\section{Availability of data and materials}

The datasets used and/or analysed during the current study are available from the corresponding author on reasonable request.

\section{Declarations}

Ethics approval and consent to participate Not applicable. All protocols were duly observed during interaction with respondents and participants.

\section{Consent for publication}

The authors have approved this manuscript for submission to the BMC Journal of Agriculture and Food Security. All authors have read and approved the manuscript and it has not been published previously nor is it being considered by any other peer-reviewed journal.

\section{Competing interests}

The authors declare that they have no competing interests.

\section{Author details}

'Department of Agricultural Extension and Rural Development, University of Ibadan, Ibadan, Nigeria. ${ }^{2}$ Department of Environmental Management, Institute of Life and Earth Sciences, Pan Africa University (PAULESI) University of Ibadan, Ibadan, Nigeria.

Received: 12 October 2020 Accepted: 6 January 2022

Published online: 01 March 2022

\section{References}

1. Chemining'wa G, Mulagoli I, Mwonga S, Ndubi J, Tum J, Turyamureeba G. Kabale apples: boom or burst? A study to develop strategies to exploit market opportunities for apple farmers in Kabale, Uganda. 2021. http://erepository.uonbi.ac.ke/handle/11295/89191. Accessed 31 Aug 2021.

2. Llanes R, Otomo E, De Las AR, Edwards G. Apples and peaches in tropical lowlands of the Philippines. Acta Hortic. 1987;199:64-64.

3. Hermano F, Ben-ek J, Vargas T, Edwards G. Apples and peaches in tropical highlands of the Philippines. Acta Hortic. 1987;199:63-63.

4. Subhadrabandhu S, Punsri P. Deciduous fruit trees as an alternative to opium poppy in Northern Thailand. Acta Hortic. 1987;199:39-44.

5. Edwards G. Potential for apple production in Venezuela. Acta Hortic. 1987;199:19-25.

6. Niegel W. The growing of deciduous fruits in Ecuador. Acta Hortic. 1992;310:23-34.

7. Hoffman MO. Observations on apple production in Peru. Acta Hortic. 1987;199:31-31.

8. Hauser K. Apple variety list. 2021. https://www.kuffelcreek.com/apple list.htm. Accessed 1 Sept 2021.

9. Giesberger G. Growing deciduous fruit trees in the tropics-a new approach to an old problem. Acta Hortic. 1975;49:109-12.

10. Alum P, Magherini R. Apple production in strictly tropical zones: first observations in Nigeria. Acta Hortic. 1995;409:25-38.

11. Griesbach J. Growing temperate fruit trees in Kenya. 2007. http://apps. worldagroforestry.org/downloads/Publications/PDFS/b15496.pdf.

12. Hauser K. The complete guide to growing apples where they're not supposed to. Kuffel Creek Press PO Box 2663 Riverside, CA 92516 USA, 2012. www.kuffelcreek.com.

13. Food and Agricultural Organisation of the United Nations (FAO). FAOSTAT; 2018. www.fao.org/faostat/en/\#data/QC. Accessed 8 Aug 2020.

14. Nairaland. Apple cultivation in Nigeria. https://www.nairaland.com/ 1922692/apple-cultivation-nigeria-pictures/7. Accessed 6 May 2019.

15. Brookings. The start of a new poverty narrative. https://www.brook ings.edu/blog/future-development/2018/06/19/the-start-of-a-newpoverty-narrative/. Accessed 8 Aug 2020

16. World Bank. Population, total-Nigeria 2019 data. https://data.world bank.org/indicator/SP.POP.TOTL?locations=NG. Accessed 8 Aug 2020.

17. World Bank. Population, total—India 2019 data. https://data.world bank.org/indicator/SP.POP.TOTL?locations=IN. Accessed 8 Aug 2020.

18. Bravo-Ureta B, Solís D, Cocchi H, Quiroga R. The impact of soil conservation and output diversification on farm income in Central American hillside farming. Agric Econ. 2006;35(3):267-76.

19. Harris D, Orr A. Is rainfed agriculture really a pathway from poverty? Agric Syst. 2014;123:84-96.

20. Oladele O. Contribution of indigenous vegetables and fruits to poverty alleviation in Oyo State, Nigeria. J Hum Ecol. 2011;34(1):1-6.

21. Weinberger K, Lumpkin T. Diversification into horticulture and poverty reduction: a research agenda. World Dev. 2007;35(8):1464-80. 
22. Statista. Global production of fruits by variety. 2017. www.statista.com. Accessed 9 Mar 2019.

23. Frederick C, Liu M, Bugang W. Fresh deciduous fruit annual report. China; 2015.

24. Department of Agriculture, Forestry and Fisheries (DAFF). A profile of the South African Apple Market Value. Republic of South Africa. 2016. www.daff.gov.za.

25. Girmay G, Menza M, Mada M, Abebe T. Empirical study on apple production, marketing, and its contribution to household income in Chencha district of Southern Ethiopia. Sch J Agric Sci. 2014;4(3):166-75.

26. Olawoye JE. Presentation for the institution strengthening workshop on participatory extension for lleogbo community. December 13-14, 2011.

27. Eeuwijk P, Angehrn Z. How to conduct a focus group discussion. 2017. http://www.zora.uzh.ch/id/eprint/150640/1/Focus_Group_Discussion_ Manual_van_Eeuwijk_Angehrn_Swiss_TPH_2017.pdf

28. Gemignani $\bar{M}$. Minimum participants for a focus group interview? FAQS.TIPS. 2020. https://faqs.tips/post/minimum-participants-for-afocus-group-interview.html. Accessed 1 Sept 2021.

29. Morgan D. Minimum participants for a focus group interview? -FAQS. TIPS. 2020. https://faqs.tips/post/minimum-participants-for-a-focusgroup-interview.html. Accessed 1 Sept 2021.

30. Osike S. Minimum participants for a focus group interview? —FAQS TIPS. 2020. https://faqs.tips/post/minimum-participants-for-a-focusgroup-interview.html. Accessed 1 Sept 2021.

31. Kachnic F. How do you best combine focus groups and individual interviews in qualitative research?. 2021. https://www.researchgate. net/post/How-do-you-best-combine-focus-groups-and-individualinterviews-in-qualitative-research/604f70ab1 b7eba7f16529eac/citat ion/download. Accessed 1 Sept 2021.

32. Morgan D. How do you best combine focus groups and individual interviews in qualitative research. 2014. https://www.researchgate.net/ post/How-do-you-best-combine-focus-groups-and-individual-inter views-in-qualitative-research/542090edd685cc7c048b45d6/citation/ download. Accessed 1 Sept 2021.

33. Olawoye JE. Qualitative data collection methods in agricultural extension research. In: Research methods in agricultural extension. Ilorin, AESON/ARMTI, 2004. pp. 101-126.

34. Olawoye JE. A case study of community: university collaborative development. Ileogbo: Bukshi Prints and Publishing; 2014.

35. World Bank. Gender in agriculture source book. World Bank. 2009 http://www.worldbank.org.html. Accessed 25 Sept 2017.

36. Fetena S, Shara S, Anjulo A, Gulie G. Survey on apple production and variety identification in Chencha district. J Agric Food Technol. 2014;4(5):7-15.

37. Timoteos H. Hope in apples. 2008. http://bibalex.org/baifa/Attac hment/Documents/171485.pdf. Accessed 1 Sept 2021.

38. Oyibo O. Effects of sweet potato production on empowerment of farming households in Niger-Delta, Nigeria. Ph.D. Post - Data Seminar, Department of Agricultural Extension and Rural Development, Faculty of Agriculture, University of Ibadan; 2021.

\section{Publisher's Note}

Springer Nature remains neutral with regard to jurisdictional claims in published maps and institutional affiliations.

Ready to submit your research? Choose BMC and benefit from:

- fast, convenient online submission

- thorough peer review by experienced researchers in your field

- rapid publication on acceptance

- support for research data, including large and complex data types

- gold Open Access which fosters wider collaboration and increased citations

- maximum visibility for your research: over $100 \mathrm{M}$ website views per year

At BMC, research is always in progress.

Learn more biomedcentral.com/submissions 